\title{
A Computer Program for Estimating Instream Travel Times and Concentrations of a Potential Contaminant in the Yellowstone River, Montana
}

By Peter M. McCarthy

In cooperation with Montana Department of Environmental Quality

Scientific Investigations Report 2006-5057 


\section{U.S. Department of the Interior \\ Gale A. Norton, Secretary \\ U.S. Geological Survey \\ P. Patrick Leahy, Acting Director}

\section{U.S. Geological Survey, Reston, Virginia: 2006}

For product and ordering information:

World Wide Web: http://www.usgs.gov/pubprod

Telephone: 1-888-ASK-USGS

For more information on the USGS--the Federal source for science about the Earth, its natural and living resources, natural hazards, and the environment:

World Wide Web: http://www.usgs.gov

Telephone: 1-888-ASK-USGS

Any use of trade, product, or firm names is for descriptive purposes only and does not imply endorsement by the U.S. Government.

Although this report is in the public domain, permission must be secured from the individual copyright owners to reproduce any copyrighted materials contained within this report.

Suggested citation:

McCarthy, P.M., 2006, A computer program for estimating instream travel times and concentrations of a potential contaminant in the Yellowstone River, Montana: U.S. Geological Survey Scientific Investigations Report 2006-5057, 16 p. 


\section{Contents}

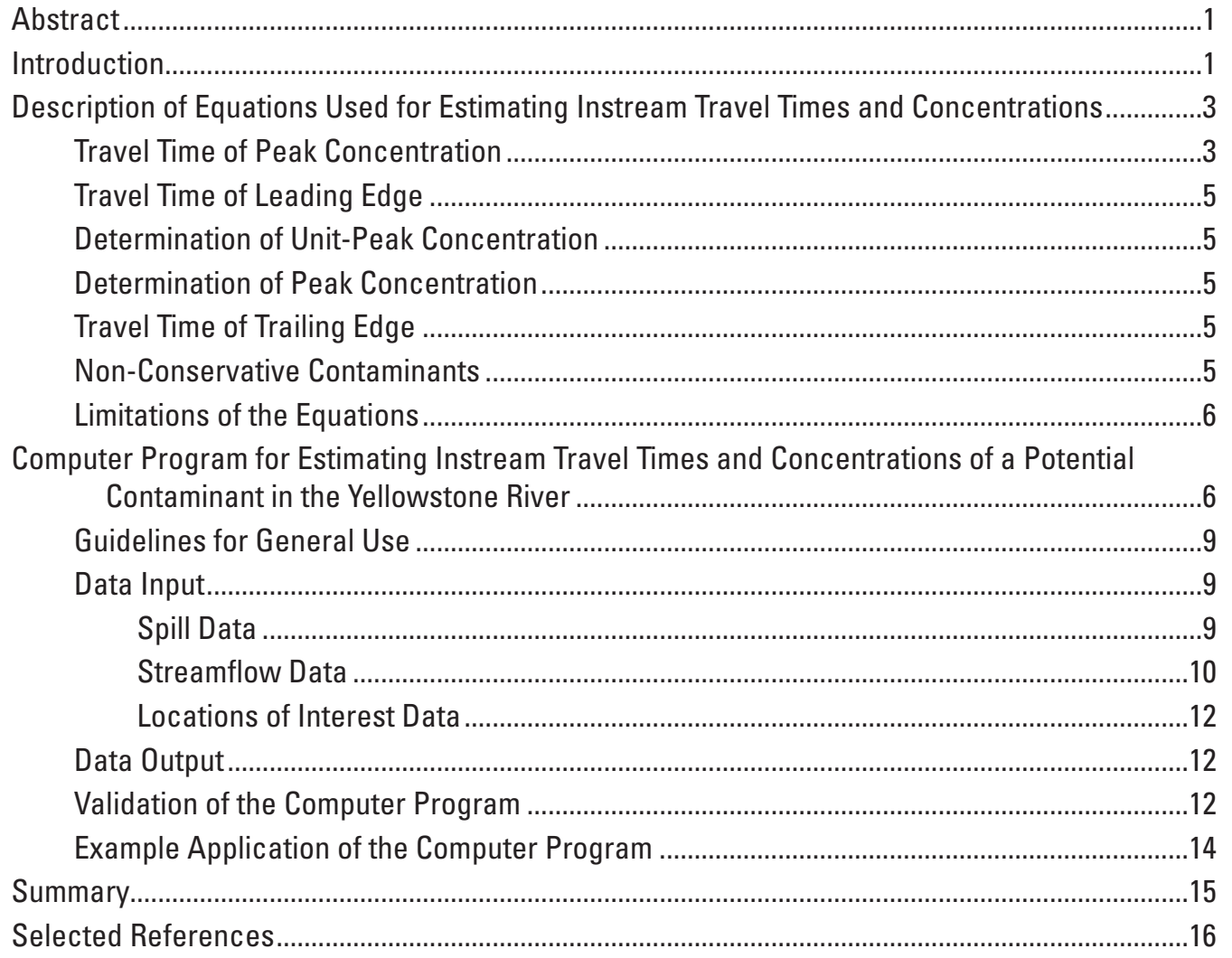

\section{Figures}

1. Map showing streamflow-gaging stations, river reaches, nodes, and major tributaries along the Yellowstone River from Corwin Springs to Sidney, Montana...........2

2. Diagram showing a typical graph of travel times and concentrations for the movement of a contaminant plume past a fixed point downstream from a spill. ..............3

3-4. Schematic diagrams showing:

3. Interpolation of mean-annual discharge and instantaneous discharge for nodes located at confluences of major tributaries...................................................8

4. Discharge adjustment by drainage-area method......................................................

5-10. Computer-screen shots showing parts of pop-up windows for:

5. Input form for contaminant-spill location, recovery ratio, and mass.........................10

6. Input form for contaminant list and for adding or deleting contaminants.................10

7. Input form for discharge data. ...................................................................................

8. Data-management buttons for loading, saving, and deleting streamflow

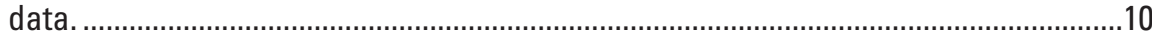

9. Input form for selecting locations of interest. ......................................................12

10. Function for graphing instream travel times and concentrations. ............................12 


\section{Tables}

1. Bankfull and low-flow discharge values for selected sites along the Yellowstone River, Montana.

2. Real-time streamflow-gaging stations along the Yellowstone River and major tributaries, Montana, 2006

3. River mileages for selected locations along the Yellowstone River, Montana................11

4. Stream-velocity data for selected storm hydrographs at selected streamflow-gaging stations, Yellowstone River, Montana.

\section{Conversion Factors, Datum, and Acronyms}

\begin{tabular}{lll}
\hline \multicolumn{1}{c}{ Multiply } & \multicolumn{1}{c}{ By } & \multicolumn{1}{c}{ To obtain } \\
\hline cubic foot per second $\left(\mathrm{ft}^{\mathrm{t}} / \mathrm{s}\right)$ & 0.02832 & cubic meter per second $\left(\mathrm{m}^{3} / \mathrm{s}\right)$ \\
foot $(\mathrm{ft})$ & 0.3048 & meter $(\mathrm{m})$ \\
foot per foot $(\mathrm{ft} / \mathrm{ft})$ & 1.0 & meter per meter $(\mathrm{m} / \mathrm{m})$ \\
foot per mile $(\mathrm{ft} / \mathrm{mi})$ & 0.1894 & meter per kilometer $(\mathrm{m} / \mathrm{km})$ \\
foot per second $(\mathrm{ft} / \mathrm{s})$ & 0.3048 & meter per second $(\mathrm{m} / \mathrm{s})$ \\
foot per second squared $\left(\mathrm{ft} / \mathrm{s}^{2}\right)$ & 0.3048 & meter per second squared $\left(\mathrm{m} / \mathrm{s}^{2}\right)$ \\
gallon $(\mathrm{gal})$ & 3.785 & liter $(\mathrm{L})$ \\
gallon $($ gal) & 0.003785 & cubic meter $\left(\mathrm{m}^{3}\right)$ \\
mile $(\mathrm{mi})$ & 1.609 & kilometer $(\mathrm{km})$ \\
mile per hour $(\mathrm{m} / \mathrm{h})$ & 1.609 & kilometer per hour $(\mathrm{km} / \mathrm{h})$ \\
pound, avoirdupois $(\mathrm{lb})$ & 0.4536 & kilogram $(\mathrm{kg})$ \\
pound, avoirdupois $(\mathrm{lb})$ & 453,600 & milligram $(\mathrm{mg})$ \\
square mile $\left(\mathrm{mi}{ }^{2}\right)$ & 2.590 & square kilometer $\left(\mathrm{km}{ }^{2}\right)$ \\
\hline
\end{tabular}

Horizontal coordinate information is referenced to the North American Datum of 1927 (NAD 27).

Concentrations of chemical constituents in water are given either in milligrams per liter (mg/L) or micrograms per liter $(\mu \mathrm{g} / \mathrm{L})$.

\section{Acronyms used in this report:}

dbf database file

GIS geographic information system

TOT time-of-travel

USGS U.S. Geological Survey

VB Visual Basic 


\title{
A Computer Program for Estimating Instream Travel Times and Concentrations of a Potential Contaminant in the Yellowstone River, Montana
}

\author{
By Peter M. McCarthy
}

\section{Abstract}

The Yellowstone River is very important in a variety of ways to the residents of southeastern Montana; however, it is especially vulnerable to spilled contaminants. In 2004, the U.S. Geological Survey, in cooperation with Montana Department of Environmental Quality, initiated a study to develop a computer program to rapidly estimate instream travel times and concentrations of a potential contaminant in the Yellowstone River using regression equations developed in 1999 by the U.S. Geological Survey. The purpose of this report is to describe these equations and their limitations, describe the development of a computer program to apply the equations to the Yellowstone River, and provide detailed instructions on how to use the program. This program is available online at http://pubs.water.usgs.gov/sir2006-5057/.

The regression equations provide estimates of instream travel times and concentrations in rivers where little or no contaminant-transport data are available. Equations were developed and presented for the most probable flow velocity and the maximum probable flow velocity. These velocity estimates can then be used to calculate instream travel times and concentrations of a potential contaminant.

The computer program was developed so estimation equations for instream travel times and concentrations can be solved quickly for sites along the Yellowstone River between Corwin Springs and Sidney, Montana. The basic types of data needed to run the program are spill data, streamflow data, and data for locations of interest along the Yellowstone River. Data output from the program includes spill location, river mileage at specified locations, instantaneous discharge, mean-annual discharge, drainage area, and channel slope. Travel times and concentrations are provided for estimates of the most probable velocity of the peak concentration and the maximum probable velocity of the peak concentration.

Verification of estimates of instream travel times and concentrations for the Yellowstone River requires information about the flow velocity throughout the $520 \mathrm{mi}$ of river in the study area. Dye-tracer studies would provide the best data about flow velocities and would provide the best verification of instream travel times and concentrations estimated from this computer program; however, data from such studies does not currently (2006) exist and new studies would be expensive and time-consuming. An alternative approach used in this study for verification of instream travel times is based on the use of flood-wave velocities determined from recorded streamflow hydrographs at selected mainstem streamflow-gaging stations along the Yellowstone River. The ratios of flood-wave velocity to the most probable velocity for the base flow estimated from the computer program are within the accepted range of 2.5 to 4.0 and indicate that flow velocities estimated from the computer program are reasonable for the Yellowstone River. The ratios of flood-wave velocity to the maximum probable velocity are within a range of 1.9 to 2.8 and indicate that the maximum probable flow velocities estimated from the computer program, which corresponds to the shortest travel times and maximum probable concentrations, are conservative and reasonable for the Yellowstone River.

\section{Introduction}

The Yellowstone River is very important in a variety of ways to the residents of southeastern Montana. The Yellowstone River originates in Yellowstone National Park, and flows about 545 river miles to the Montana-North Dakota State line (fig. 1). The Yellowstone River is an important source of irrigation water and, in some areas of Montana, is a blueribbon trout stream. Additionally, the Yellowstone River is the primary source of municipal water for the cities of Laurel, Billings, Lockwood, Forsyth, Miles City, and Glendive. Other communities along the Yellowstone River obtain their municipal water from shallow alluvial aquifers adjacent to the Yellowstone River and its tributaries.

The Yellowstone River valley serves as a primary eastwest transportation corridor through Montana. Transportation infrastructure within this corridor includes Interstate highways I-90 and I-94; Montana Rail Link and Burlington Northern Santa Fe Railroads; and many State highways, county roads, and city streets. Most of these highways, railroads, and roads cross or come within $500 \mathrm{ft}$ of the Yellowstone River. Therefore, the Yellowstone River is especially vulnerable to 


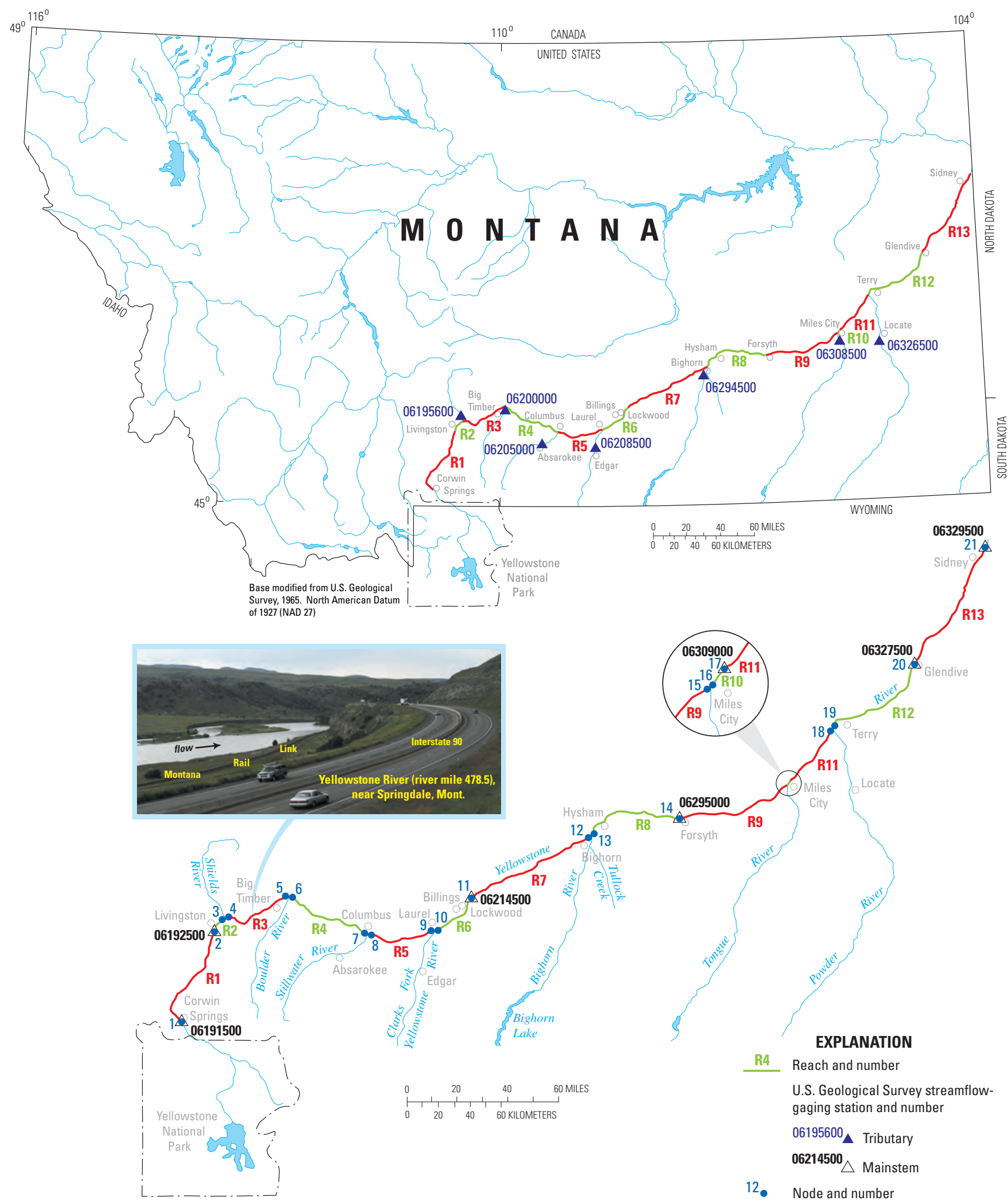

Figure 1. Streamflow-gaging stations, river reaches, nodes, and major tributaries along the Yellowstone River from Corwin Springs to Sidney, Montana. 
contaminants that might be spilled while moving along these transportation corridors. The threat of contamination is a concern for water-resource managers and planners, municipal water-supply personnel, and emergency-response personnel.

Preparing for contaminant spills and responding to them in a timely fashion are important parts of protecting drinking-water supplies. Estimated instream travel times and contaminant concentrations are important considerations when preparing for or responding to contaminant spills into the river. Although several hydraulic models are available to estimate travel times and concentrations, these models require detailed information about flow velocities, channel geometry, and flow-resistance coefficients, and might require calibration using dye-tracer methods. Obtaining the required hydraulic information and using dye-tracer methods for calibration are time-consuming and expensive. Because time and funding are not always available, a quick and inexpensive method was needed to provide reliable estimates for instream travel times and concentrations.

In 1999, Jobson developed equations to estimate instream travel times and contaminant concentrations with little data about the stream. Jobson's (1999) equations were based on time-of-travel data from numerous dye-tracer studies conducted throughout the United States. In 2004, the U.S. Geological Survey (USGS), in cooperation with Montana Department of Environmental Quality, initiated a study to develop a computer program to rapidly estimate instream travel times and concentrations of a potential contaminant in the Yellowstone River using Jobson's (1999) equations.

The purpose of this report is to describe the computer program developed for this study to estimate instream travel times and concentrations for the Yellowstone River. Specifically, this report describes Jobson's (1999) equations and their limitations. The report also describes the development of a computer program to apply Jobson's (1999) equations to the Yellowstone River, and provides detailed instructions on how to use the program for an example spill scenario. This program is available online at http://pubs.water.usgs. gov/sir2006-5057/.

\section{Description of Equations Used for Estimating Instream Travel Times and Concentrations}

Equations developed by Jobson (1999) provide estimates of instream travel times and concentrations in rivers where little or no data are available. The equations were developed from dye-tracer injection measure- ments made at more than 980 stream subreaches from about 90 different rivers with varying drainage areas, slopes, meanannual discharges, and instantaneous discharge at the time of the tracer injection. Equations were developed and presented for the most probable flow velocity and the maximum probable flow velocity. Each velocity equation could then be used to calculate instream travel times and concentrations of potential contaminants. The travel times of a potential contaminant include travel time of the peak concentration $\left(C_{p}\right)$ of the contaminant plume $\left(T_{p}\right)$, the travel time of the leading edge of the contaminant plume $\left(T_{l}\right)$, and travel time of the trailing edge of the contaminant plume where the contaminant concentration is reduced to 10 percent of the peak concentration $\left(T_{10 d}\right)$. Figure 2 represents the travel times for the typical movement of a contaminant plume past a fixed point downstream from a spill. A computer program was developed to facilitate the application of Jobson's (1999) equations for the Yellowstone River.

\section{Travel Time of Peak Concentration}

The travel time of the peak concentration of a dissolved contaminant to a specific location downstream from a spill is determined from the velocity of the peak concentration, which is related to channel geometry and hydraulic characteristics of the stream. Jobson (1999) used multiple regression analysis to relate the velocity of the peak concentration to drainage area, reach slope, mean-annual discharge, and instantaneous discharge. The multiple regression analysis was simplified by using drainage area, mean-annual discharge, and instantaneous discharge to define three dimensionless variables for velocity of the peak concentration, drainage area, and relative discharge (equations 1 through 3 ).

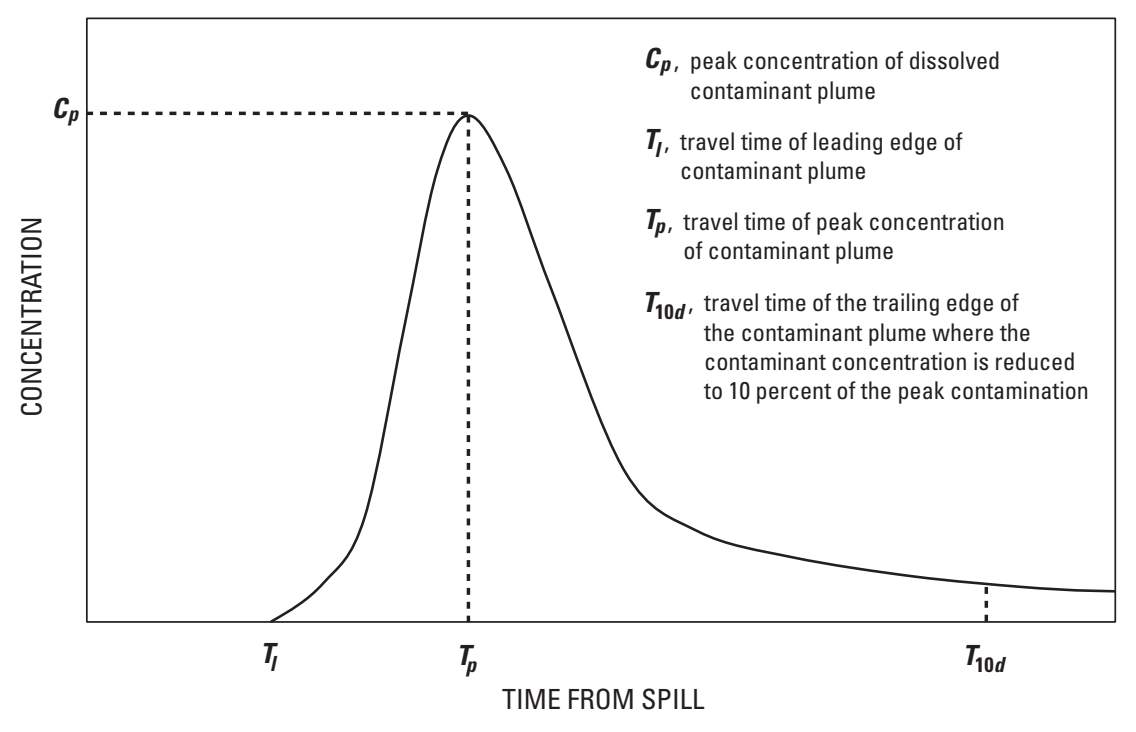

Figure 2. A typical graph of travel times and concentrations for the movement of a contaminant plume past a fixed point downstream from a spill. 
The equation for the dimensionless velocity of the peak concentration is:

$$
\bar{V}_{p}=\frac{V_{p} D_{a}}{Q}
$$

where

$\bar{V}_{p} \quad$ is the dimensionless velocity of the peak concentration of the dissolved contaminant;

$V_{p} \quad$ is the velocity of the peak concentration of the dissolved contaminant, in meters per second;

$D_{a} \quad$ is the drainage area, in meters squared; and

$Q \quad$ is the instantaneous discharge, in cubic meters per second.

The equation for dimensionless drainage area is:

$$
\bar{D}_{a}=\frac{D_{a}^{1.25} \sqrt{g}}{Q_{a}}
$$

where

$\bar{D}_{a} \quad$ is the dimensionless drainage area;

$g \quad$ is the acceleration of gravity, equal to 9.806 meters per second squared;

$Q_{a}$ is the mean-annual discharge, in cubic meters per second; and

all other terms are as previously defined.

The equation for the dimensionless relative discharge is:

$$
\overline{Q_{a}}=\frac{Q}{Q_{a}}
$$

where

$$
\bar{Q}_{a} \quad \text { is the dimensionless relative discharge, and }
$$

all other terms are as previously defined.

Dimensionless peak velocity, drainage area, and relative discharge were used to determine the velocity of the peak concentration of the dissolved contaminant. The velocity of the peak concentration $\left(V_{p}\right)$ can be determined as either the most probable velocity $\left(V_{p m p}{ }^{p}\right.$ ) or the maximum probable velocity $\left(V_{p m x}\right)$. Equation 4 (Jobson, 1999) provides the most probable velocity estimate for the peak concentration for the dissolved contaminant:

$$
V_{p m p}=0.094+0.0143\left(\bar{D}_{a}\right)^{0.919}\left(\bar{Q}_{a}\right)^{-0.469} S^{0.159} \frac{Q}{D_{a}}
$$

where

$V_{p m p}$ is the most probable velocity of the peak concentration of the dissolved contaminant, in meters per second;

$S \quad$ is the reach slope, in meters per meter; and all other terms are as previously defined.

Although equation 4 provides the most probable velocity estimate, the maximum probable velocity, which corresponds to the maximum probable concentration and shortest probable travel time to a specific point of interest, might be of more interest to water-supply managers. Thus, equation 5 (Jobson, 1999), which calculates the maximum probable velocity of the peak concentration of the dissolved contaminant, was derived so that 99 percent of the observed velocities were smaller than those calculated from equation 5 (Jobson, 1999):

$$
V_{p m x}=0.25+0.02\left(\bar{D}_{a}\right)^{0.919}\left(\bar{Q}_{a}\right)^{-0.469} S^{0.159} \frac{Q}{D_{a}}
$$

where

$$
\begin{aligned}
& V_{p m x} \text { is the maximum probable velocity of the } \\
& \text { peak concentration of the dissolved } \\
& \text { contaminant, in meters per second; and }
\end{aligned}
$$
all other terms are as previously defined.

The travel time of the peak concentration is calculated using the velocity of the peak concentration of the dissolved contaminant. Equations 4 and 5 both provide velocity estimates of the peak concentration and can be used interchangeably in equation 6 to determine travel-time estimates:

$$
T_{p}=\frac{L}{3,600 V_{p}}
$$

where

$T_{p} \quad$ is the time required for the peak concentration of the contaminant to travel from the spill location to the location of interest, in hours;

$L \quad$ is the distance from the spill location to the location of interest, in meters; and

$V_{p} \quad$ is the velocity of the peak concentration of the contaminant calculated from equation 4 or 5 , in meters per second.

Use of the velocity $\left(V_{p m p}\right)$ from equation 4 will result in the most probable travel time while use of the velocity $\left(V_{p m x}\right)$ from equation 5 will result in the shortest probable travel time. 


\section{Travel Time of Leading Edge}

A strong linear correlation exists between the travel time of the leading edge and the travel time of the peak concentration (Jobson, 1999), and this travel time can be estimated from the following equation:

$$
T_{l}=0.890 T_{p}
$$

where

$T_{l} \quad$ is the time required for the leading edge of the dissolved contaminant plume to travel from the spill location to the location of interest, in hours; and

all other terms are as previously defined.

\section{Determination of Unit-Peak Concentration}

The unit-peak concentration is defined as 1,000,000 times the peak concentration produced in a unit discharge due to the injection of a unit mass of a conservative contaminant (Jobson, 1999). The unit-peak concentration is needed to determine the peak concentration of a contaminant and the travel time of the trailing edge. Data were compiled by Jobson (1999) from 410 stream cross sections representing a wide range of stream size, reach slope, and geomorphic type to define the relation between the unit-peak concentration of the contaminant, drainage area, mean-annual discharge, and instantaneous discharge. From these data, regression analysis was used to develop an estimation equation (Jobson, 1999):

$$
C_{u p}=857 T_{p}^{-0.760}\left(Q / Q_{a}\right)^{-0.079}
$$

where

$$
\begin{aligned}
& C_{u p} \quad \text { is the unit-peak concentration of the } \\
& \text { contaminant, per second; and }
\end{aligned}
$$

all other terms are as previously defined.

\section{Determination of Peak Concentration}

Water-supply managers can use peak concentration information to determine whether estimated contaminant concentrations in water supplies might be within an acceptable range for use. The peak concentration of a potential contaminant plume is a function of the unit-peak concentration, mass of the contaminant spilled, and the instantaneous discharge.

The peak concentration can be estimated from:

$$
C_{p}=\frac{C_{u p} R_{r} M_{i}}{1 \times 10^{9} Q}
$$

where

$C_{p} \quad$ is the peak concentration of the dissolved contaminant plume, in milligrams per liter;

$R_{r} \quad$ is the recovery ratio, or the ratio of the mass of dissolved contaminant that was recovered to the mass of the dissolved contaminant that was spilled;

$M_{i} \quad$ is the mass of soluble contaminant spilled, in milligrams; and

all other terms are as previously defined.

\section{Travel Time of Trailing Edge}

The time required for a dissolved contaminant plume to entirely pass a point of interest is essential for water-supply managers to determine how long water-supply intakes need to be shut down. Unfortunately, the time required for a contaminant to completely pass a point cannot be clearly defined because longitudinal dispersion can continue indefinitely. However, the time required for the contaminant concentration to reduce to 10 percent of the peak concentration can be estimated and used to approximate the time of passage of the contaminant (Kilpatrick and Taylor, 1986):

$$
T_{10 d}=\frac{2 \times 10^{6}}{3,600 C_{u p}}+T_{i}
$$

where

$T_{10 d}$ is the travel time of the trailing edge of the contaminant plume where the contaminant concentration is reduced to 10 percent of the peak concentration, in hours;

$C_{u p}$ is the unit-peak concentration of the contaminant, per second; and

all other terms are as previously defined.

\section{Non-Conservative Contaminants}

The methods presented in this report for estimating unit-peak concentration do not account for losses in mass of the contaminant during transit from the spill location to the location of interest. The equations and the computer program developed for use with data for the Yellowstone River are based on the assumptions that contaminants are conservative and do not lose mass during transit (conservative transport). Such an approach will generally provide a high estimate of unit-peak concentration because losses in mass normally occur from chemical and physical processes, such as oxidation reactions, photochemical decay, volatilization, sorption onto sediments, or a combination of these processes (Jobson, 1999). Jobson (1999) presents one approach to estimate the loss of non-conservative contaminants by use of a decay function 
that exponentially reduces the mass of the non-conservative contaminant as a function of travel time:

$$
M_{i a}=M_{i} e^{-k T_{p}}
$$

where

$M_{i a} \quad$ is the apparent mass, in milligrams, of dissolved contaminant that was spilled after a time of $T_{p}$;

$M_{i} \quad$ is the mass of non-conservative contaminant that was spilled, in milligrams;

$e \quad$ is the natural exponential function and is approximately equal to 2.718 ;

$k \quad$ is the decay coefficient, per hour; and all other terms are as previously defined.

\section{Limitations of the Equations}

The equations for estimation of instream travel times and concentrations developed by Jobson (1999) have some limitations. The regression equations (equations 4, 5, 7, and 8) were developed from data measured during conditions of steady flow in 90 different rivers throughout the United States, where the discharge at a single location does not vary substantially over time. When large fluctuations in streamflow occur, the travel times are greatly affected, and the equations cannot accurately estimate the travel times and concentrations. Additionally, the peak concentration $\left(C_{p}\right.$, equation 9$)$ is dependent on uniform flow conditions (equation 3 ) within a river reach, where the discharge does not vary substantially with distance. Changes in relative discharge with distance in a given reach might result in inaccurate calculations of peak concentration (equation 9).

The regression equations also were developed from data obtained under generally low or normal flow conditions. Thus, use of the estimation equations for very high or very low flows might result in unreliable estimates of travel times and concentrations. In particular, flows that exceed the bankfull discharge (assumed to be equivalent to the annualpeak discharge with a 2-year recurrence interval) will result in overbank flows with velocities and flow paths that can be very different from those in the main channel. Contaminants in water that has overflowed streambanks might never return to the main channel. Likewise, during very low-flow conditions (assumed to be equivalent to the 1-day, 2-year annual low-flow discharge), stream water and contaminants can be stored for long periods of time in pools and slackwater areas. Table 1 presents approximate bankfull and low-flow discharge values for selected sites along the Yellowstone River. The equations are likely to provide unreliable estimates of instream travel times and concentrations for discharge values greater than the bankfull discharge or less than the low-flow discharge.
Finally, the estimation equations for instream travel time and concentrations were developed for contaminants dissolved in water. Thus, contaminants which do not dissolve in water will likely behave differently. Instream travel times and concentrations for non-dissolved contaminants cannot be reliably estimated with these equations.

\section{Computer Program for Estimating Instream Travel Times and Concentrations of a Potential Contaminant in the Yellowstone River}

A computer program was developed so estimation equations for instream travel times and concentrations can be solved quickly for sites along the Yellowstone River between Corwin Springs and Sidney, Montana. The program is designed only for use on the Yellowstone River but can be revised for use on other river systems. This reach of the Yellowstone River is 520 river miles long and currently (2006) has seven active, real-time streamflow-gaging stations (table 2, fig. 1). At Corwin Springs (station 06191500), the upstreammost station in the reach, the average channel slope (reach slope) is $13.9 \mathrm{ft} / \mathrm{mi}$, the drainage area upstream from the gaging station is 2,619 $\mathrm{mi}^{2}$ (U.S. Geological Survey, 2005), and the mean-annual discharge is $3,120 \mathrm{ft}^{3} / \mathrm{s}$ (McCarthy, 2005). At Sidney (station 06329500), the downstream-most station in the reach, the average channel slope (reach slope), is $2.5 \mathrm{ft} / \mathrm{mi}$, the drainage area upstream from the gaging station is $69,083 \mathrm{mi}^{2}$ (U.S. Geological Survey, 2005), and the mean-annual discharge is $12,300 \mathrm{ft}^{3} / \mathrm{s}$ (McCarthy, 2005). Between Corwin Springs and Sidney, seven major tributaries join the Yellowstone River: Shields River, Boulder River, Stillwater River, Clarks Fork Yellowstone River, Bighorn River, Tongue River, and Powder River (table 2, fig. 1).

The Yellowstone River from Corwin Springs to Sidney could not be treated as a single reach for estimation of instream travel times and concentrations because the river typically has highly variable streamflow and geomorphic conditions. Thus, the Yellowstone River was divided into 13 reaches (fig. 1), each having somewhat similar streamflow and geomorphic conditions. For the computer program, reach ends (nodes, fig. 1) were established at confluences with major tributaries and real-time streamflow-gaging station sites. At the confluences, two nodes were established, one immediately upstream from the confluence and another immediately downstream from the confluence. Each node was assigned the same river mileage (fig. 1). The purpose of having two nodes at each major confluence is to ensure that large differences in streamflow and geomorphic data would not occur within a reach. 
Table 1. Bankfull and low-flow discharge values for selected sites along the Yellowstone River, Montana.

[Station number is U.S. Geological Survey number, wherein the first two digits indicate the major river basin and the remaining 6 digits indicate a downstream station order. Abbreviation: $\mathrm{ft}^{3} / \mathrm{s}$, cubic feet per second]

\begin{tabular}{clcc}
\hline $\begin{array}{c}\text { Station number } \\
\text { (fig. 1) }\end{array}$ & \multicolumn{1}{c}{ Station name } & $\begin{array}{c}\text { Bankfull discharge }{ }^{1} \\
\text { (ft } \mathbf{3} / \mathbf{s})\end{array}$ & $\begin{array}{c}\text { Low-flow discharge }^{2} \\
\left.\text { (ft }^{3} \mathbf{s} \mathbf{s}\right)\end{array}$ \\
\hline 06191500 & Yellowstone River at Corwin Springs & 17,500 & 641 \\
06192500 & Yellowstone River near Livingston & 20,300 & 877 \\
06214500 & Yellowstone River at Billings & 40,100 & 3,230 \\
06295000 & Yellowstone River at Forsyth & 45,700 & 1,840 \\
06309000 & Yellowstone River at Miles City & 48,700 & 2,020 \\
\hline
\end{tabular}

${ }^{1}$ Bankfull discharges are the annual-peak discharge with a 2-year recurrence interval (Parrett and Johnson, 2004).

${ }^{2}$ Low-flow discharges are the 1-day, 2-year annual low-flow discharges (McCarthy, 2005).

Table 2. Real-time streamflow-gaging stations along the Yellowstone River and major tributaries, Montana, 2006.

[Station number is U.S. Geological Survey number, wherein the first two digits indicate the major river basin and the remaining 6 digits indicate a downstream station order. Abbreviations: $\mathrm{ft}^{3} / \mathrm{s}$, cubic foot per second; $\mathrm{ft} / \mathrm{mi}$, foot per mile. Symbol: --, no data]

\begin{tabular}{clccc}
\hline $\begin{array}{c}\text { Station number } \\
\text { (fig. 1) }\end{array}$ & \multicolumn{1}{c}{ Station name } & $\begin{array}{c}\text { Mean annual } \\
\text { discharge', } \\
\text { in ft's }\end{array}$ & Period of record ${ }^{2}$ & $\begin{array}{c}\text { Channel slope, } \\
\text { in ft/mi }\end{array}$ \\
\hline 06191500 & Yellowstone River at Corwin Springs & 3,120 & $1910-2002$ & 13.9 \\
06192500 & Yellowstone River near Livingston & 3,730 & $1900-2002$ & 11.1 \\
06195600 & Shields River near Livingston & 279 & $1979-2002$ & -- \\
06200000 & Boulder River at Big Timber & 566 & $1947-2002$ & -- \\
06205000 & Stillwater River near Absarokee & 86 & $1910-2002$ & -- \\
06208500 & Clarks Fork Yellowstone River at Edgar & 1,030 & $1921-2002$ & -- \\
06214500 & Yellowstone River at Billings & 6,970 & $1904-2002$ & 10.4 \\
06294500 & Bighorn River above Tullock Creek, near Bighorn & 3,860 & $1965-2002$ & -- \\
06295000 & Yellowstone River at Forsyth & 10,600 & $1977-2002$ & 4.7 \\
06308500 & Tongue River at Miles City & 409 & $1938-2002$ & -- \\
06309000 & Yellowstone River at Miles City & 11,800 & $1966-2002$ & 3.2 \\
06326500 & Powder River near Locate & 576 & $1938-2002$ & -- \\
06327500 & Yellowstone River at Glendive & 13,300 & $1900-1934$ & 3.2 \\
06329500 & Yellowstone River near Sidney & 12,300 & $1966-2002$ & 2.5 \\
\hline
\end{tabular}

${ }^{1}$ The computed mean-annual discharge might not consistently increase in the downstream direction, primarily because the period of record is not the same for all streamflow-gaging stations.

${ }^{2}$ Period of record for which mean-annual discharge was determined (McCarthy, 2005). 


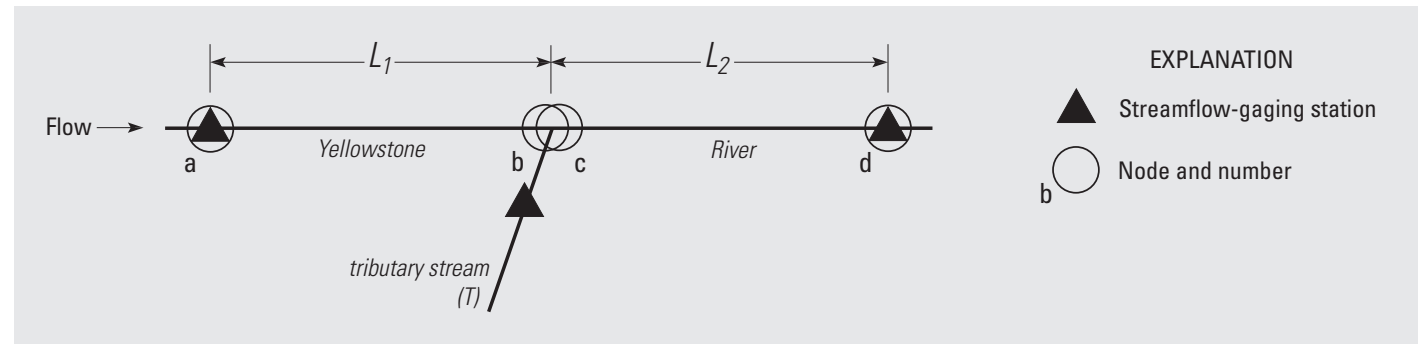

Figure 3. Interpolation of mean-annual discharge and instantaneous discharge for nodes located at confluences of major tributaries.

Available data for each node include the mean-annual discharge, drainage area, river mileage, and reach slope. Streamflow data for nodes located at gaging stations are obtained from historical gage information, whereas streamflow data for nodes at confluences are calculated by linear interpolation of data between upstream and downstream gaging stations (fig. 3) using the following equations:

$$
\begin{gathered}
Q_{b}=\frac{\left(Q_{d}-Q_{T}\right) L_{1}+Q_{a} L_{2}}{L_{1}+L_{2}} \\
Q_{c}=Q_{b}+Q_{T}
\end{gathered}
$$

where

$Q_{b} \quad$ is the discharge immediately upstream from the confluence at node $b$, in cubic meters per second;

$Q_{d} \quad$ is the discharge at the streamflow-gaging station downstream from the confluence at node $d$, in cubic meters per second;

$Q_{T} \quad$ is the discharge at the streamflow-gaging station of the tributary stream $(T)$ near the confluence, in cubic meters per second;

$L_{1} \quad$ is the reach length from node $a$ to node $b$, in kilometers;

$Q_{a} \quad$ is the discharge at the streamflow-gaging station upstream from the confluence at node $a$, in cubic meters per second;

$L_{2} \quad$ is the reach length from node $c$ to node $d$, in kilometers; and

$Q_{c} \quad$ is the discharge immediately downstream from the confluence at node $c$, in cubic meters per second.

Similarly, the drainage area for each of the two nodes at major tributary confluences may be calculated by:

$$
D A_{b}=\frac{\left(D A_{d}-D A_{T}\right) L_{1}+D A_{a} L_{2}}{L_{1}+L_{2}}
$$

$$
D A_{c}=D A_{b}+D A_{T}
$$

where

$D A_{b} \quad$ is the drainage area immediately upstream from the confluence at node $b$, in square kilometers;

$D A_{d} \quad$ is the drainage area at the streamflow-gaging station downstream from the confluence at node $d$, in square kilometers;

$D A_{T} \quad$ is the drainage area at the streamflowgaging station of the tributary stream $(T)$, near the confluence, in cubic meters per second;

$L_{1} \quad$ is the reach length from node $a$ to node $b$, in kilometers;

$D A_{a}$ is the drainage area at the streamflowgaging station upstream from the confluence at node $a$, in square kilometers;

$L_{2} \quad$ is the reach length from node $c$ to node $d$, in kilometers; and

$D A_{c} \quad$ is the drainage area immediately down stream from the confluence at node $c$, in square kilometers.

In some instances, the gaging station on the tributary can be a substantial distance upstream from the confluence, such as Powder River near Locate (fig. 1). Therefore, the meanannual discharge and instantaneous-discharge data from the gage might require some adjustment to represent the discharge of the tributary at the confluence. In these instances, the square root of the ratio of the drainage area of the tributary at the confluence to the drainage area of the tributary at the gaging station is used as a multiplier to adjust the discharge data from the gaging station that is on the tributary (fig. 4):

$$
Q_{T, C}=Q_{T, G}\left(\frac{D A_{C}}{D A_{G}}\right)^{0.5}
$$

where

$Q_{T, C} \quad$ is the discharge of the tributary stream $(T)$ at the confluence with the Yellowstone River, in cubic meters per second; 


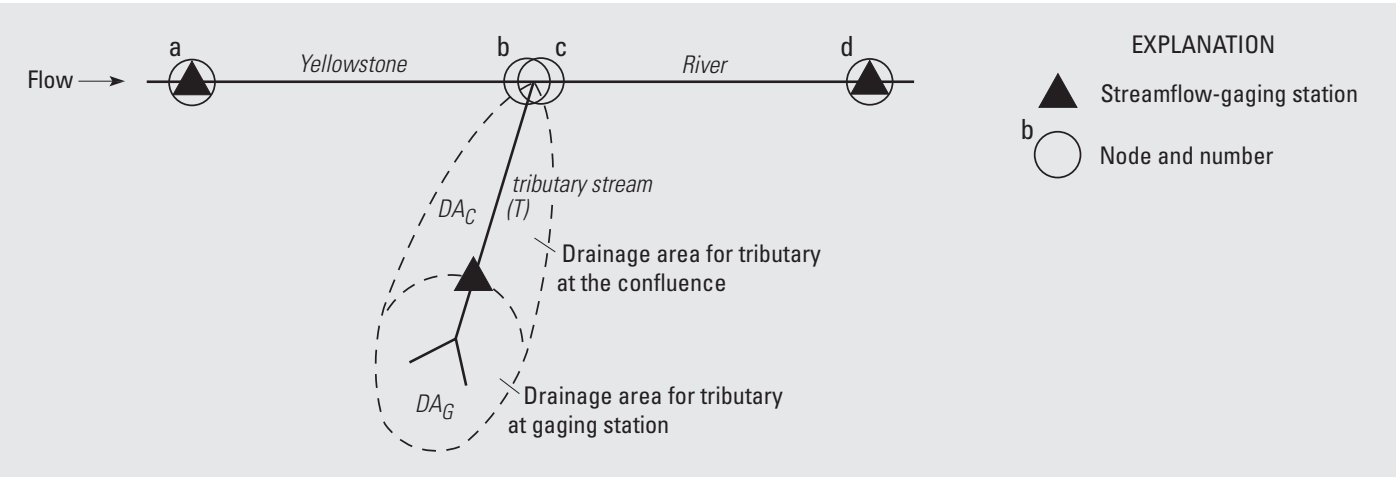

Figure 4. Discharge adjustment by drainage-area method.

$Q_{T, G}$ is the discharge of the tributary stream $(T)$ at the gaging station, in cubic meters per second;

$D A_{C}$ is the entire drainage area of the tributary stream $(T)$ at the confluence with the Yellowstone River, in square kilometers; and

$D A_{G}$ is the drainage area of the tributary stream $(T)$ at the gaging station, in square kilometers.

The use of 13 reaches with nodes at streamflow-gaging station locations and tributary confluences was designed to ensure that discharges would not change substantially within any reach. Nevertheless, large fluctuations in discharge can occur owing to irrigation diversions, irrigation return flows, and ground-water interaction. As the discharge within a reach decreases due to irrigation diversions and seepage into the ground-water system, losses in dissolved contaminant mass will occur and the observed concentrations will continue to decrease as the contaminant moves downstream even though the equations developed by Jobson (1999) would show an increase in dissolved contaminant concentrations. The computer program will not allow the dissolved contaminant concentration within any given reach to increase.

Based on the equations developed by Jobson (1999), this program treats all spills as slug injections, where the contaminant is spilled instantaneously into the river. For contaminants that might slowly leak into the river, the superposition principle (Jobson, 1999) can be applied in conjunction with the program to estimate the time of travel for the leading edge and the maximum concentration of the contaminant at a location downstream from the spill.

\section{Guidelines for General Use}

The computer program is developed using Microsoft Visual Basic 6.3 (VB) in Microsoft Excel 2002 (Microsoft, 2002). Macros must be enabled for the program to work. The main Excel file contains VB code and three worksheets: "InputData," "OutputData," and "SavedFlows." Tabs for these three worksheets are located at the bottom of the Excel window. The "SavedFlows" worksheet is hidden from view because this sheet does not normally require any user input or edits. Data in this worksheet are automatically edited through the management tools provided for loading, saving, and deleting flow conditions. However, manual edits can be made directly in the worksheet if desired. Within the other two worksheets, buttons have been provided to assist navigation to desired worksheet locations as necessary. Users are warned that both the "InputData" and "OutputData" worksheets have additional data essential to the program computations that must not be changed or deleted.

\section{Data Input}

The program is designed to allow several options for data input while maintaining ease of use. The basic types of data needed to run the program are spill data, streamflow data, and locations of interest data along the Yellowstone River. Each of these basic types of data has several input options. Input for the program is placed in the "InputData" worksheet in Excel.

\section{Spill Data}

The program requires information related to a potential spill-river mileage at the spill location, recovery ratio of the contaminant, and mass of the spilled contaminant (fig. 5). The river mileage at a spill location can be determined from table 3, which presents river mileages at key locations, such as streamflow-gaging stations and tributary confluences (Montana Department of Natural Resources and Conservation, 1976). The mileages presented in table 3 might differ from distances that are measured from a map or from a geographic information system (GIS) because the Yellowstone River most likely changed after the river mileages were determined by the Montana Department of Natural Resources and Conservation (1976). Two limitations about the location of the contaminant spill include: (1) a contaminant spill must be located along the Yellowstone River mainstem, and (2) a contaminant spill 
location must be confined to the reaches bounded by nodes at Corwin Springs and Sidney (fig. 1). Although the program will appear to work for spill locations specified upstream from Corwin Springs and downstream from Sidney, the calculated values might not be reliable.

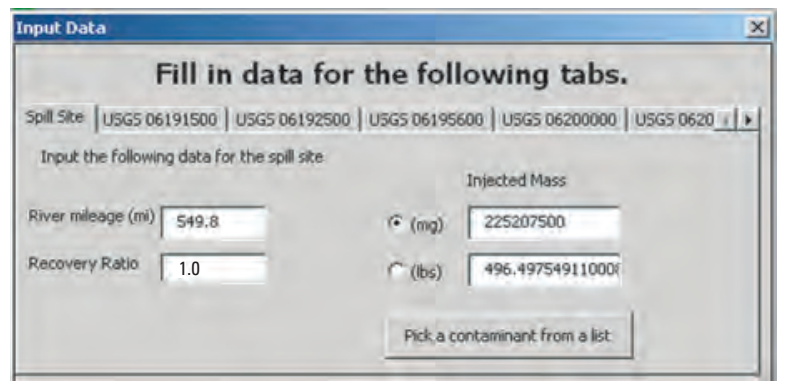

Figure 5. Input form for contaminant-spill location, recovery ratio, and mass.

In the program, conservative transport is assumed for any potential contaminant. Thus, the mass of contaminant moving downstream is equal to the mass of contaminant spilled, resulting in a recovery ratio $\left(R_{r}\right.$, equation 9$)$ of 1.0. However, some contaminants might lose mass in transit due to chemical and physical processes (non-conservative transport). The recovery ratio can be set to values less than 1.0. The recovery ratio for non-conservative contaminants can be estimated as:

$$
R_{r}=\frac{M_{i a}}{M_{i}}
$$

where all terms are as previously defined.

The equation for estimating the peak concentration (equation 9) requires the mass of contaminant spilled, in milligrams. Because other units for contaminant spills are more commonly used, the user can enter either the mass of the contaminant in milligrams (mg) or the weight in pounds (lb) (fig. 5). Additionally, the program will determine the mass of the contaminant from the volume spilled. The user can select a contaminant from a dropdown list (fig. 6) or add a constituent and its specific weight. The volume spilled (in gallons) is needed for the program to calculate the mass of the spilled contaminant. Contaminants can be added or deleted from the contaminant list by using the "Add Item to List" and "Delete Item from List" buttons provided on the contaminant list (fig. 6).
Contaminants added to the list need to be soluble in water and must be conservatively transported downstream as previously described.

\section{Streamflow Data}

The program requires discharge data for the 14 streamflow-gaging stations along the Yellowstone River and its major tributaries (fig. 1). An input tab for each streamflow-gaging station (fig. 7) is provided that allows users to input discharge data (in cubic feet per second). An Internet link to the USGS real-time streamflow Web page for each particular station is provided so that real-time discharge data can be retrieved and used in the program.

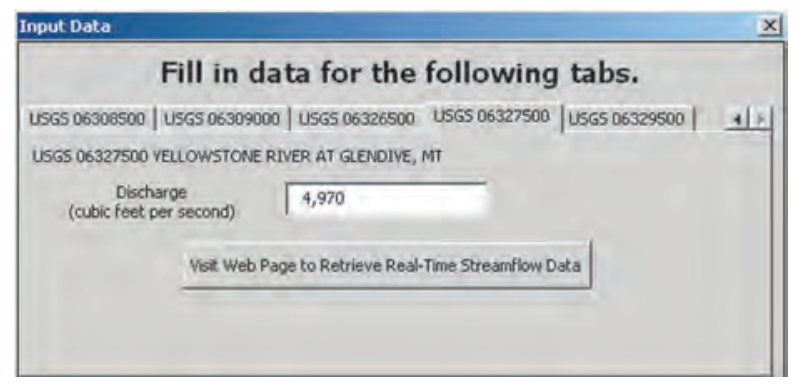

Figure 7. Input form for discharge data.

Data-management functions are used to load and save discharge data (fig. 8). The "Load REAL-TIME Streamflow Data" button can be used to automatically obtain the most current real-time discharge data for all 14 stations (fig. 1). Three other functions also have been provided in the program to save, load, or delete a specific set of discharge data for the 14 stations. These functions are accessed by clicking the "Save Streamflow Data," "Load a Saved Streamflow Data Set," and "Delete a Saved Streamflow Data Set" buttons. Discharge data are saved in the "SavedFlows" worksheet in Excel with the "Save Streamflow Data" button (fig. 8).

At times, the real-time streamflow data automatically loaded from the USGS Web pages might be zero or have an alpha code (such as "Ice" for ice conditions at the station). The program will not accept zero values or alpha codes and will instruct the user to correct those streamflow values. For these instances, a small value of discharge, such as $1 \mathrm{ft}^{3} / \mathrm{s}$, can be used to represent zero flow, and the discharge at the nearest upstream or downstream station can be used to estimate the flow when data from a site has an alpha code. In other

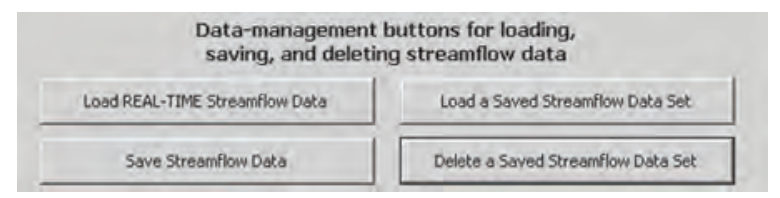

Figure 8. Data-management buttons for loading, saving, and deleting streamflow data. 
instances, several streamflow-gaging stations may have ice conditions at the gage. The user can choose to use the meandaily streamflow instead of the flow value for the nearest station that does not have iced conditions. The mean-daily streamflow for each station is available on the USGS realtime streamflow Web pages and can be accessed by clicking the "Visit Web Page to Retrieve Real-Time Streamflow Data" button (fig. 7).

Table 3. River mileages for selected locations along the Yellowstone River, Montana.

[River mileages from Montana Department of Natural Resources and Conservation (1976). River mileages not in parentheses are those used in the computer program; those river mileages in parentheses are the approximate river mileages for selected population centers along the Yellowstone River. Nodes are those locations previously defined and shown in figure 1. Eight-digit station-identification numbers for surface-water sites represent the standard U.S. Geological Survey numbering systems for streamflow-gaging stations, wherein the first two digits indicate the major river basin and the remaining 6 digits indicate a downstream station order. All locations are in Montana. Abbreviation: mi, mile. Symbol: --, no node number assigned]

\begin{tabular}{|c|c|c|}
\hline Node & Selected locations along the Yellowstone River & River mileage (miles) \\
\hline 1 & Streamflow-gaging station 06191500 (Yellowstone River at Corwin Springs) & 549.7 \\
\hline 2 & Streamflow-gaging station 06192500 (Yellowstone River near Livingston) & 501.4 \\
\hline-- & Livingston & (495 to 499$)$ \\
\hline 3,4 & At confluence of Shields River near Livingston & 489.0 \\
\hline-- & Big Timber & (457 to 459$)$ \\
\hline 5,6 & At confluence of Boulder River near Big Timber & 456.0 \\
\hline 7,8 & At confluence of Stillwater River near Columbus & 413.1 \\
\hline-- & Columbus & (411 to 413$)$ \\
\hline-- & Laurel & 381.8 (381 to 382$)$ \\
\hline 9,10 & At confluence of Clarks Fork Yellowstone River near Laurel & 379.2 \\
\hline-- & Billings & $362.2(357$ to 370$)$ \\
\hline-- & Lockwood, 1 mi northeast of Billings & 360.4 \\
\hline 11 & Streamflow-gaging station 06214500 (Yellowstone River at Billings) & 360.3 \\
\hline 12 & At confluence of Bighorn River near Bighorn & 295.6 \\
\hline-- & Hysham & $(273$ to 275$)$ \\
\hline-- & Forsyth & 238.3 (237 to 239$)$ \\
\hline 14 & Streamflow-gaging station 06295000 (Yellowstone River at Forsyth) & 238.2 \\
\hline-- & Miles City & $185.1(182$ to 186$)$ \\
\hline 15,16 & At confluence of Tongue River near Miles City & 185.0 \\
\hline 17 & Streamflow-gaging station 06309000 (Yellowstone River at Miles City) & 184.2 \\
\hline 18,19 & At confluence of Powder River near Terry & 149.5 \\
\hline-- & Terry & (137 to 139$)$ \\
\hline 20 & Streamflow-gaging station 06327500 (Yellowstone River at Glendive) & 93.0 \\
\hline-- & Glendive & 92.1 (93 to 96$)$ \\
\hline-- & Sidney & (30 to 33 ) \\
\hline 21 & Streamflow-gaging station 06329500 (Yellowstone River near Sidney) & 29.2 \\
\hline
\end{tabular}




\section{Locations of Interest Data}

The computer program provides estimates of instream travel times and concentrations for specified sites in the "Select Locations of Interest" form (fig. 9). Six major communities along the Yellowstone River are identified as locations of interest for which estimates of instream travel times and concentrations can be determined. In addition, the program allows up to three locations of interest to be specified by the user; river mileage is required for each of these locations. If a location of interest lies upstream from the spill location, the location of interest is automatically deselected when the program is executed.

\section{Data Output}

Output from the program is placed in the "OutputData" worksheet and organized into three categories: "Spill Data," "Locations of Interest Data," and "Streamflow-Gaging Station and Tributary Data." Each of these categories is presented so the user can easily view the data after each run of the program.

The computer program will list the primary data for the spill location, which includes river mileage, instantaneous discharge, mean-annual discharge, drainage area, channel slope, and mass of the spill. The river mileage and mass of the spill come directly from the data that were input by the user. The instantaneous discharge, mean-annual discharge, drainage area, and channel slope are calculated based on characteristics of the reach where the spill occurs. The calculations, except for channel slope, are based upon linear interpolation of those values between the two nodes defining the reach (fig. 3 ) in which the spill occurs. The channel slope at the spill location is determined by the channel slope of the reach in which the spill occurs and is calculated by dividing the difference in elevation of the nodes bounding the reach by the river distance between the two nodes.

Finally, the computer program lists the primary data for streamflow-gaging station nodes and the most downstream node at major tributary confluences (fig. 1). The primary data include river mileage at the location of interest, instantaneous discharge, mean-annual discharge, drainage area, and the channel slope. Travel times and concentrations are provided for both estimates of flow velocity for the peak concentration: the most probable velocity of the peak concentration $\left(V_{p m p}\right.$, equation 4$)$ and the maximum probable velocity of the peak concentration ( $V_{p m x}$, equation 5). Thus, the primary data presented for nodes at confluences represents the effects of the added discharge from the tributaries.

The computer program provides additional options for data display from the "Make Graphs of Results" tab in the "OutputData" worksheet (fig. 10). The user can graphically display the results of travel-time estimates for up to 5 of the 23 locations at one time. The graphs are only intended for quick, visual reference and are not intended to be presentationquality graphs. Data output can be saved and used in other software for higher-quality graphical displays.

The "Make copy of OutputData sheet" button (fig. 10) allows users to save the most recently compiled data. Copying output data is encouraged because any new compilations of the program will overwrite previous data. Users need to be aware that the worksheet names "InputData" and "OutputData" are required for program operation and should not be changed.

Two separate functions have been provided to output data in dbf files for a GIS. The first function ("Create *.dbf file from existing output data" button) saves the output data in $\mathrm{dbf}$ format. The second function ("Calculate TOT for user defined mileage steps" button) will calculate instream travel times and concentrations along the entire Yellowstone River from the spill site to Sidney for user-entered mileage steps, and save the output in dbf format. Both functions allow the user to name and save the dbf files.

\section{Validation of the Computer Program}

The estimates of instream travel times and concentrations provided by the program are based on regression equations (Jobson, 1999) developed from data collected outside of Montana. Verification of estimates for instream travel times and concentrations for the Yellowstone River requires information about the flow velocity throughout the $520 \mathrm{mi}$ of river in the study area. Information from dye-tracer injection studies would provide the best data about flow velocities and, thus, would provide the best verification of instream travel times and concentrations that are estimated from this computer pro-

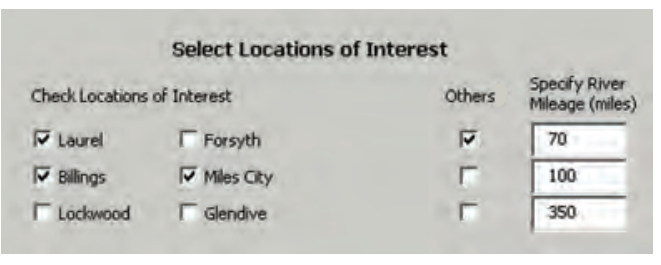

Figure 9. Input form for selecting locations of interest.

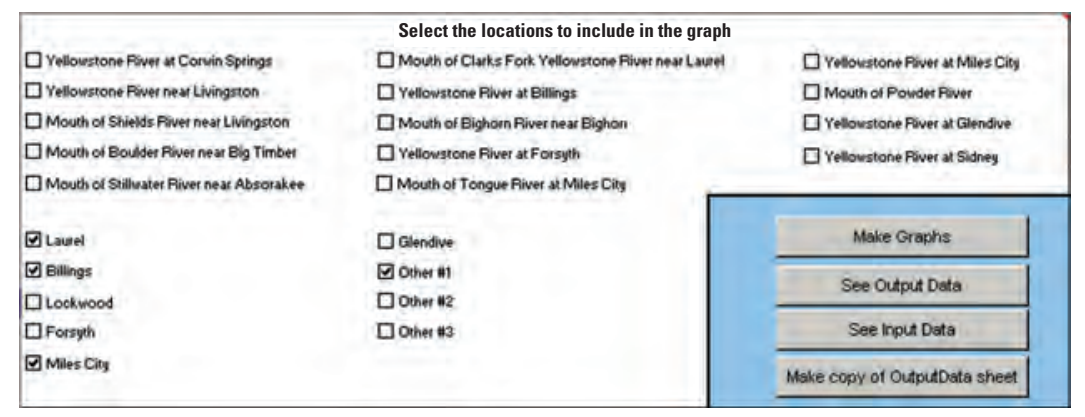

Figure 10. Function for graphing instream travel times and concentrations. 
gram. However, data from such studies do not currently (2006) exist and new studies would be expensive and time-consuming.

An alternative approach used in this study for verification of instream travel times is based on the use of recorded streamflow hydrographs at mainstem streamflow-gaging stations along the Yellowstone River. Hydrographs at two or more stations on the Yellowstone River were reviewed for peak discharges that were the result of large thunderstorms (storm hydrographs). The difference in river mileage at two stations divided by the arrival time of the peak discharge provides an estimate of the velocity of a flood wave moving between the two stations. The velocity of a flood wave is the sum of the base-flow velocity of a stream and the velocity of the flood wave relative to the base-flow velocity (wave celerity, Chow, 1959):

$$
V_{f w}=c+V_{b f}
$$

where

$V_{f w} \quad$ is the velocity of the flood wave, in meters per second;

c is the wave celerity, in meters per second; and

$V_{b f} \quad$ is the velocity of base flow, in meters per second.
The wave celerity of a flood wave generally ranges from 1.5 to 3.0 times faster than the base-flow velocity of the stream, depending upon base-flow depth and whether streamflow is laminar or turbulent (Julien, 2002):

$$
c=(1.5 \text { to } 3.0) V_{b f}
$$

where all terms are as previously defined.

In streams where flow is turbulent, the wave celerity is about 1.5 times the base-flow velocity; in streams where flow is laminar, the wave celerity is about 3.0 times the base-flow velocity. Thus, substituting equation 19 into equation 18 , the velocity of a flood wave generally ranges from 2.5 to 4.0 times that of the base-flow velocity.

Flood-wave velocities were estimated for two storm events. During November 2001, one storm event caused a flood wave to move through two reaches, while in September 2002 another storm event caused a flood wave to move through five reaches. Table 4 shows the results of the floodwave velocity estimates between the six mainstem stations on the Yellowstone River (fig. 1) for these two events.

These estimates of flood-wave velocity are compared to the most probable and maximum probable flow velocity estimated for the base flow of the hydrograph for each reach by the computer program. For the storm of November 2001, the ratio of flood-wave velocity to the most probable flow velocity ranged from 3.1 to 3.2 in the two reaches, and the

Table 4. Stream-velocity data for selected storm hydrographs at selected streamflow-gaging stations, Yellowstone River, Montana.

[All values are determined for the reach upstream from each station. For example, the flood-wave velocity of 3.9 miles per hour for station 06192500 on September 8, 2002, was calculated using the reach from station 06192500 upstream to station 06191500 (R1, fig. 1). Abbreviation: mi/h, miles per hour. Symbol: --,

\begin{tabular}{|c|c|c|c|c|c|c|}
\hline $\begin{array}{l}\text { Station number } \\
\text { (fig. 1) }\end{array}$ & $\begin{array}{l}\text { Reach number } \\
\text { (fig. 1) }\end{array}$ & $\begin{array}{c}\text { Flood-wave } \\
\text { velocity }^{1} \\
\text { (mi/h) }\end{array}$ & $\begin{array}{c}\text { Most probable } \\
\text { flow velocity }{ }^{2} \\
\text { (mi/h) }\end{array}$ & $\begin{array}{l}\text { Ratio of flood- } \\
\text { wave velocity to } \\
\text { most probable } \\
\text { flow velocity }\end{array}$ & $\begin{array}{l}\text { Maximum } \\
\text { probable flow } \\
\text { velocity }^{2} \\
(\mathrm{mi} / \mathrm{h})\end{array}$ & $\begin{array}{c}\text { Ratio of flood- } \\
\text { wave velocity to } \\
\text { maximum prob- } \\
\text { able flow velocity }\end{array}$ \\
\hline \multicolumn{7}{|c|}{ November 7, 2001} \\
\hline 06191500 & -- & -- & -- & -- & -- & -- \\
\hline 06192500 & 1 & 3.1 & 1.0 & 3.1 & 1.1 & 2.8 \\
\hline \multicolumn{7}{|c|}{ September 8, 2002} \\
\hline 06191500 & -- & -- & -- & -- & -- & -- \\
\hline 06192500 & 1 & 3.9 & 1.2 & 3.2 & 1.5 & 2.7 \\
\hline 06214500 & $2-6$ & 3.8 & 1.2 & 3.2 & 1.5 & 2.6 \\
\hline
\end{tabular}
velocities upstream from station not determined]

${ }^{1}$ Flood-wave velocity calculated using hydrograph data at selected streamflow-gaging stations.

${ }^{2}$ Most probable flow velocity (Vpmp, equation 4) and maximum probable flow velocity (Vpmx, equation 5) estimated by the computer program. 
ratio of flood-wave velocity to the maximum probable flow velocity ranged from 2.6 to 2.8 in the two reaches. For the storm of September 2002, the ratio of flood-wave velocity to the most probable flow velocity ranged from 2.5 to 3.2 in the five reaches, and the ratio of flood-wave velocity to the maximum probable flow velocity ranged from 1.9 to 2.7 in the five reaches.

Use of flood-wave velocities determined from storm hydrographs to verify estimated stream velocities is a rough approximation at best. All ratios using the most probable flow velocity are within the accepted 2.5 to 4.0 range and indicate that flow velocities estimated from the computer program are reasonable for the Yellowstone River. All of the ratios using the maximum probable flow velocities are within a 1.9 to 2.8 range and indicate that the maximum probable flow velocities estimated from the computer program, which corresponds to the shortest travel times and maximum probable concentrations, are conservative and reasonable for the Yellowstone River.

\section{Example Application of the Computer Program}

The general procedures for estimation of instream travel times and concentrations developed in this report are illustrated in the following example. This program is available online at http://pubs.water.usgs.gov/sir2006-5057/.

\section{Example 1.}

A tractor truck, pulling a trailer with 1,000 gallons of Rhodamine WT dye in solution at 20 percent, has an accident along the Yellowstone River at Livingston and the trailer's contents are released into the river. Emergency response personnel want to know how long it will take for the Rhodamine dye to reach Laurel, Billings, Miles City, and an additional Location of Interest at river mile 70. The estimated peak concentration and time of passage for each location of interest also is needed. Execution of the following instructions will generate the desired estimates.

\section{Start Microsoft Excel:}

1. Set macro security to medium by selecting Tools $\rightarrow$

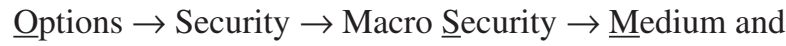
click the "OK" button.

2. Open the Excel file "YTOT.xls," and, if prompted, click "Enable Macros."

3. Click "Calculate Travel Times and Concentrations" button found on the "InputData" and "OutputData" sheets.

4. Click the "Pick a contaminant from a list" button found on the "Spill Site" tab (fig. 5).
5. Use the pull down list (fig. 6) and select "Rhodamine WT@ 20\%."

6. Input " 1,000 " into the "Input the estimated gallons spilled" and click the "OK" button.

7. Using table 3, determine the river mileage at the spill site. Enter this river mileage into the box provided.

8. Check the boxes next to "Laurel," "Billings," and "Miles City." Also check the first box under "Others" and put 70 in the first box (fig. 9). All other boxes need to be unchecked.

9. Click the "Load REAL-TIME Streamflow Data" button to automatically load the real-time flows (fig. 8). Ensure that the flows are all greater than 0.0 and that ice conditions are not occurring anywhere by clicking each station tab and viewing the discharge data (fig. 7).

10. Because further analysis and additional runs may be desired at this flow rate, click the "Save Streamflow Data" button (fig. 8). Provide a unique name for this file.

\section{Data input complete:}

11. Click the "Calculate Travel Times and Concentrations" button. When the program is finished calculating, the "OutputData" worksheet will become the active worksheet.

\section{View the data output:}

12. Click the "Make Graphs of Results" button. Note that "Laurel," "Billings," "Miles City," and "Other \#1" have been automatically selected. If previously created graphs are present, delete them by right clicking over the graphs and select "Clear."

13. Check any other desired locations and click the "Make Graphs" button (fig. 10). Reminder: If more than five locations have been selected, the graphs may be difficult to read. Note that the additional location of interest at river mile 70 is labeled as 70 in the graph.

14. Return to the data output by clicking the "See Output Data" button (fig. 10).

15. Make a copy of the output data sheet by clicking the "Make copy of OutputData sheet" button.

16. Input the desired OutputData sheet name and click the "OK" button.

17. At this point, users can create OutputData sheets for use in a GIS by using the "Create *.dbf file from existing output data" and "Calculate TOT for user defined mileage steps" buttons. 


\section{Summary}

The Yellowstone River is very important in a variety of ways to the residents of southeastern Montana; however, it is especially vulnerable to spilled contaminants. Preparing for contaminant spills and responding to them in a timely fashion are important parts of protecting drinking-water supplies. Estimated instream travel times and contaminant concentrations are important considerations when preparing for or responding to contaminant spills into the river. In 2004, the U.S. Geological Survey, in cooperation with Montana Department of Environmental Quality, initiated a study to develop a computer program to rapidly estimate instream travel times and concentrations of a potential contaminant in the Yellowstone River using regression equations developed in 1999 by the U.S. Geological Survey. The purpose of this report is to describe these equations and their limitations, describe the development of a computer program to apply the equations to the Yellowstone River, and provide detailed instructions on how to use the program. This program is available online at http://pubs.water. usgs.gov/sir2006-5057/.

The regression equations provide estimates of instream travel times and concentrations in rivers where little or no data are available. Equations were developed and presented for the most probable flow velocity and the maximum probable flow velocity. These velocity estimates can then be used to calculate instream travel times and concentrations of a potential contaminant. The travel time of the peak concentration is calculated using the velocity of the peak concentration of the dissolved contaminant. Travel-time estimates using the most probable velocity estimate will result in the most probable travel time while using the maximum probable velocity estimate will result in the shortest probable travel time. A strong linear correlation exists between the arrival time of the leading edge and the travel time of the peak concentration. The unit-peak concentration is needed to determine the peak concentration of a contaminant. The peak concentration can be used to determine whether contaminant concentrations in water supplies are within an acceptable range for use. The time required for a dissolved contaminant plume to entirely pass a point of interest cannot be clearly defined because longitudinal dispersion can continue indefinitely; however, the time required for the contaminant concentration to reduce to 10 percent of the peak concentration can be estimated.

The equations for estimation of instream travel times and concentrations have some limitations. The peak concentration is dependent on uniform flow conditions within a river reach, the use of the estimation equations for very high or very low flows might result in unreliable estimates of travel times and concentrations, and the estimation equations for instream travel time and concentrations were developed for contaminants dissolved in water.
The computer program was developed so estimation equations for instream travel times and concentrations can be solved quickly for sites along the Yellowstone River between Corwin Springs and Sidney, Montana. The basic types of data needed to run the program are spill data, streamflow data, and locations of interest data along the Yellowstone River. Data output from the program includes spill location, river mileage at specified locations, instantaneous discharge, mean-annual discharge, drainage area, and channel slope. Travel times and concentrations are provided for both estimates of flow velocity for the peak concentration: the most probable velocity of the peak concentration and the maximum probable velocity of the peak concentration. The computer program provides additional options for data display, allows users to save the most recently compiled data, and provides functions to save data in database files for use in a GIS.

Verification of estimates of instream travel times and concentrations for the Yellowstone River requires information about the flow velocity throughout the $520 \mathrm{mi}$ of river in the study area. Dye-tracer studies would provide the best data about flow velocities and would provide the best verification of instream travel times and concentrations estimated from this computer program; however, data from such studies do not currently (2006) exist and new studies would be expensive and time-consuming. An alternative approach used in this study for verification of instream travel times is based on the use of flood-wave velocities determined from recorded streamflow hydrographs at selected mainstem streamflow-gaging stations along the Yellowstone River. The velocity of a flood wave is the sum of the base-flow velocity and wave celerity. The wave celerity of a flood wave generally ranges from 1.5 to 3.0 times faster than the base-flow velocity of the stream. Thus, the velocity of a flood wave generally ranges from 2.5 to 4.0 times that of the base-flow velocity.

Flood-wave velocities were estimated for two storm events between mainstem streamflow-gaging stations along the Yellowstone River. The ratios of flood-wave velocity to the most probable velocity for the base flow are within the accepted 2.5 to 4.0 range and indicate that flow velocities estimated from the computer program are reasonable for the Yellowstone River. The ratios of flood-wave velocity to the maximum probable velocity are within a 1.9 to 2.8 range and indicate that the maximum probable flow velocities estimated from the computer program, which corresponds to the shortest travel times and maximum probable concentrations, are conservative and reasonable for the Yellowstone River. 


\section{Selected References}

Chow, V.E., 1959, Open-channel hydraulics: New York, McGraw-Hill, 680 p.

Fischer, H.B., 1967, The mechanics of dispersion in natural streams: American Society of Civil Engineers Proceedings, Journal of the Hydraulics Division, v. 90, no. SA3, p. 1-12.

Jobson, H.E., 1999, Contaminants in rivers and streams-prediction of travel time and longitudinal dispersion: Geneva, Switzerland, World Meteorological Organization Operational Hydrology Report no. 45, 49 p.

Julien, P.Y., 2002, River mechanics: New York, Cambridge University Press, 434 p.

Kilpatrick, F.A., 1993, Simulation of soluble waste transport and buildup in surface waters using tracers: U.S. Geological Survey Techniques of Water-Resources Investigations, book 3, chap. A20, 37 p.

Kilpatrick, F.A., and Taylor, K.R., 1986, Applications of dispersion data: Water Resources Bulletin, v. 22, no. 4, p. 537-548.

McCarthy, P.M., 2005, Statistical summaries of streamflow in Montana and adjacent areas, water years 1900 through 2002: U.S. Geological Survey Scientific Investigations Report 2004-5266, 317 p.

Microsoft Corporation, 2002, Microsoft Excel and Microsoft Visual Basic: Redmond, Wash., copyright (C Microsoft Corporation 1985-2001.

Montana Department of Natural Resources and Conservation, 1976, River mile index of the Yellowstone River: Water Resources Division, 61 p.

Parrett, Charles, and Johnson, D.R., 2004, Methods for estimating flood frequency in Montana based on data through water year 1998: U.S. Geological Survey Water-Resources Investigations Report 03-4308, 101 p.

U.S. Geological Survey, 2005, Water resources data, Montana, water year 2004: U.S. Geological Survey Water-Data Report MT-04-2, 2 v.

For additional information contact:

Director, Montana Water Science Center

U.S. Geological Survey

3162 Bozeman Avenue

Helena, Montana 59601

Telephone: 1-406-457-5900

World Wide Web: http://mt.water.usgs.gov/ 